\title{
Impact of Cooperative Learning on Junior Secondary School Students' Achievement in Basic Science and Technology (BST) in Akwa Ibom State, Nigeria
}

\author{
Essien Edem Udo (Ph.D.) \\ Science Education Department, University of Uyo, Uyo
}

\begin{abstract}
The study examined the impact of cooperative learning on achievement in BST among Junior Secondary School Students in Akwa Ibom State. Cooperative learning approach is an instructional strategy focusing on small groups working together to maximize their goals and learning capacities in BST. A sample of 180 students was selected for the study. Two hypotheses were formulated to guide the study. The study revealed that the participants exposed to cooperative learning strategies performed significantly higher in BST achievement tests than their control group counterparts. The study also revealed that gender has no significant impact on achievement in BST. It is therefore recommended that BST teachers should be trained on the use of cooperative learning processes.
\end{abstract}

Keywords: Cooperative Learning, Basic Science and Technology

DOI: $10.7176 / \mathrm{JEP} / 10-14-17$

Publication date:May $31^{\text {st }} 2019$

\section{Introduction}

The act of coming together to solve and complete a task seems to be effective in improving teaching and learning in school and out of school. This process makes the students to be an active learner because every student will be involved in solving one problem. It appears that some students often have an expectation that their role in the knowledge transmission process is to sit passively in class and wait for their teachers to impart the knowledge to them. This attitude, however, might lead the students to come to class unprepared, reluctant to be involved in the reasoning and discussion of the content. This may eventually lead to failure in providing two-way communication (Zahariah, Geetha, Arlinah, \& Erlane.2009). Consequently, such attitude has led the students to become more of assisted learner rather than self-directed learners which impair their ability to survive in competitive world.

To overcome such limitation, there have been calls by practitioners and universities for changes in the learning approach from teacher-centeredness to student-centeredness. One of the learning approaches that focuses on students' centeredness is cooperate learning. Cooperative learning instructional method involves small groups, each consisting of students with different levels of ability using a variety of learning activities to improve their understanding of a subjects or topic. This approach ensures that students would actively participate in the learning process rather than passively listening to their lectures (Johnson; Johnson \& smith 1998). Cooperation entails working together to accomplish shared goals. They co-operatively seek outcomes that are beneficial to all members of the group.

According to Odili (2009), the class in cooperative learning is divided into groups, with each group having a specific work to do. Also, group rewards and individual's accountability within the group are essential. The group uses a variety of learning activities in cooperative form to improve their understanding of a particular topic or subject. Each member of the group is responsible not only for learning what is taught but also for helping group mates to learn; thus creating an atmosphere of achievement (Ronsini, 2010). The uses of these groups enable students to work as a team to maximize their understanding of the subject. This is one of the aspects of cooperative learning which enhances student's academic achievement. One of the elements of cooperative learning is positive interdependence where students perceive that their success or failure lies within their working together as a group (Johnson, Johnson and Holubec, 1986).Compared to Individualist methods, it promote a positive attitude towards the instructional experience.

Cooperative learning enable students to work together and help one another to promote higher academic attainments than individualistic or competitive ones. Sapon-shevin and Schniedewind (2009) hold the view that cooperative learning is necessary in any teaching situation, because this particular strategy can foster educational excellence for all children regardless of race, class or gender, and can provide students and teacher with the experience and expectations of active participation in controlling and changing the spheres of their lives. Goor 
and Schwenn (2013) define cooperative learning as follows...' cooperative learning views students as active participants in their own learning and as future citizens who are learning to work together and share responsibilities"'.

The studies on gender difference in academic performance are highly controversial. Vijayalaxmi and Natesan (2012) assessed the academic achievement of the subjects among $11^{\text {th }}$ class students and found that girls had a higher mean score in academic achievement compared to boys. However, Kaur and Gill (2009) revealed that achievement in English and total achievement was independent of sex, but boys scored higher than girls in achievement in Mathematics, and Basic Science. Johnson, Johnson and Holubec, (1993) identified five basic elements for small group learning to be cooperative: they are: positive interdependent, face-to-face interaction, individual accountability, interpersonal and small group skills, and processing. Teachers who structure cooperative lessons include each of these elements. Briefly defined:

- Positive interdependence: students must perceive that they "'sink or swim together.'

- Face-to-face interaction: being physically close to each other promotes interaction. They should be seated eye-to-eye and knee-to-knee.

- Individual accountability: each group member is responsible for mastering the material.

- Interpersonal and small group skills: students must be taught the social skills needed for collaboration and be motivated to use them.

- Processing: students analyse how well their learning groups are functioning and the extent to which students are employing social skills.

Two theories that support the use of cooperative learning approach in improving students' performance are motivational model and cognitive model. Slavin, (2011) suggested that motivational model occurs when students work together towards a common goal as they do when cooperative learning takes places, their efforts would be directed towards helping each other to learn and succeed. Similarly, Wittrock, (2008) argued that cognitive model would make the students to be active learners and be able to elaborate and explain the material learned to other students in order to retain the information. Within the education literature, there are studies that have focused on cooperative learning approach and its impact on students' performance (Johnson and Johnson, 1987; Whicker, Bol and Nunnery, 1997; Yamarick, 2007).

The Motivational and Cognitive models use experimental setting in determining the influence of cooperative learning approach to students' performance. These studies found that participants who were exposed to cooperative learning approach performed better than those participants who used conventional approach. Studies that have examined the link between cooperative learning approach and students' performance have focused on various fields. The fields include calculus (Whicker, et. al., 1997 ), food and nutrition (Abu and Flowers, 2009) and engineering (Felder, et. al., 1998; Brooks, et. al. 2002), studies that examined the link between cooperative learning approach and students' performance in the field of Basic Science are limited compared to other fields (Yamarick, 2007). One attribute to such limitation is that most Basic Science teachers tend to use predominantly teaching method (Benzing and Christ, 2007). Becker and Watts, (2001) found in their survey that students who took Basic Science classes devote only a small amount of time involving discussion.

Within the Basic Science education literature, although limited, there are a number of studies that examined the link between cooperative learning and students' performance (Moore, 1998; Johnson, Johnson and Stanne, 2000; Jensen and Owen, 2001; Brooks and Khandker, 2002; Yamarick, 2007). The results are mixed. Few studies showed that students using the cooperative learning approach tend to perform better than those student relying on conventional approach (Moore, 1998; Brooks and Khendker, 2002; Yamarick, not provide conclusive evidence on the link between cooperative learning approach and students' performance, particularly when teaching Basic Science subject as science related subjects.

\section{Method of study}

The inconsistency in students' academic achievement in Basic Science has been a concern to all stake holders. This could be a result of teaching and learning approaches by teachers (teacher-centered) and lack of required skills in teaching the subject. It is on this basis that the researcher examined the impact of cooperative learning on junior secondary schools students' achievement in Akwa Ibom State. Two hypotheses were generated and analysed using ANCOVA. The study is relevant to teachers, students, policy makers because it will help them to identify weaker and stronger students. This would enable the weaker students learn from the stronger students and by so doing, achievement in Basic Science will improve.

This section also present the following: research design, area of study, population, sample and sampling techniques. Quasi-experiment pre-test/post-test control group design was used for this study. This research 
design is considered appropriate for use in educational research where it is not possible to randomize subjects (students) into groups. This is to avoid disrupting school activities, consequently, intact classes was used.

The study was carried out In Akwa Ibom State in South-South, Nigeria. Akwa Ibom state is located in SouthSouth sub-region of Nigeria on the West Coast of Africa. Akwa Ibom was created on September 23, 1987. It has 31 Local Government Areas officially recognized by the Federal Government of Nigeria and 3 Senatorial Districts. Akwa Ibom State has quite number of Secondary and Tertiary institutions. While the State is an Ibibiospeaking environment, it is a socio cultural oil producing state attracting both Nigerians and foreigners alike. The target population for the study comprised junior Secondary School 11 students in Akwa Ibom State. The accessible population consisted of all male and female Junior Secondary School II students in Ibiono Ibom Local Government Area in Akwa Ibom state.

Simple random sampling was used to select Ibiono Local Government Area of Akwa Ibom state. Four public coeducational Junior Secondary Schools in Akwa Ibom state were selected through hat and draw methods. Stratified random sampling technique was used to obtain the initial sample of two hundred and four (204) students from the four Junior Secondary Schools selected for the study. The base-line assessment for the study was done by administering the Basic Science Achievement Test (BSAT) on the students. Only participants whose score ranged between 0 and 49 were qualified for the main study because they perform below 50 percent $(50 \%)$ of the total score 100 . In this study, 60 participants scored above 50 in BSAT while the final sample for the main study was 180 JS 11 students.

Fifty multiple choice item tests with 4 options was developed by the researcher which attracted 50 marks. The BSAT was used as pre-test to measure the entry behaviour of the students before exposing them to training and the same instrument was used for post-test to measure performance after being exposed to training. A test-blue print was also developed to enable the researcher construct test items based on content and behavioural objectives of topic under study. The items covered only the topic studied during the training period and it has a high stability co-efficient of .73 at .05 level of significance when tested during the pilot study which made it appropriate to use for the study.

Copies of the questionnaires were given to some experts in Measurement and Evaluation, for content validity. Their comments were used to refine the instruments. A pilot study was carried out before the main study to have a try-out of the instruments and to determine their psychometric properties.30 students consisting of 15 boys and 15 girls were randomly selected to participate in the exercise. BSAT instrument was administered to a set of JS 11 students and after two weeks it was re-administered to the same set of JS 11 students. The results of the two tests was analysed using Pearson Product Moment Correlation statistics to estimate the test-retest reliability coefficient. The test-retest reliability indices of BSAT of 0.77 was obtained.

The researcher prepares lesson note on topics and infuse cooperative learning on each topics to be taught (Work, Energy, and Power). Lessons were held twice a week and each class lasted for 2 period ( 80 minutes) for a period of four weeks.

\section{Pre-training Assessment}

- $\quad$ The researcher established a rapport with the participants by stating the purpose of the study.

- Administration of all research instruments to the participants for pre-assessment.

Cooperative on Work, Energy and Power

- The researcher introduced and explain the topic (Work, Energy and Power) to the participants to enable them understand the concept.

- $\quad$ Researcher divided participants into groups and gave subtask on Work, Energy and Power to study intensively.

- $\quad$ Researcher guided the group to appoint a leader for each group to co-ordinate their learning activities on Work, Energy and Power.

- Members of the groups with the same subtasks come together to discuss about the topics Work, Energy and Power

- Members returned to their original groups and teach their mates about the subtasks on Work, Energy and Power.

- The researcher gave participants room for questions in areas not clear. 
- $\quad$ Evaluation: researcher asked participants in their various groups to solve questions relating to the above topics. For example: State the mathematical relationship between Work, Energy and Power; and Name the S.I units of Work, Energy and Power.

- The researcher moved round to see if they are actually working together in solving the problem.

- Participants analysed the result in groups.

- The various groups later wrote their own conclusion based on the result found

- The researcher posed problem to the participants on the above topics to assess their team work in solving problem on work, energy and power.

- $\quad$ Researcher collects, marks scripts and explains further on how to answer questions as team members.

- $\quad$ Researcher gave out assignments to the participants on work, energy and power.

Revision: Researcher reviewed the lesson taught.

Post Administration of Instruments:

- The Researcher distributed all the instruments to the participants for post-test scores.

- Students answered all the questions posed to them.

- The researcher collected all the instruments from the participants for post-test.

The control group was chosen from another location that was far from the experimental schools to avoid experimental contamination. During the first session, personal data questionnaire (PDQ) and Basic Science Achievement Test (BSAT) were administered to the participants. The participants were taught the same topics for the same duration as the training group by the researcher but did not receive training on cooperative learning. In addition, normal weekly class test were conducted and in the fourth week, post tests were administered.

Data Analysis and Presentation

Hypothesis one: There is no significant difference in post-test Basic Science Scores of students exposed to cooperative learning training and those not exposed to the training.

Table 1: Descriptive data on pre and post scores of the participants across the experimental conditions.

\begin{tabular}{lccccll}
\hline Group & \multicolumn{3}{c}{ pre-test } & \multicolumn{2}{l}{ post-test } \\
\hline \multirow{2}{*}{ Training Group } & $\mathrm{N}$ & Mean & SD & Mean & SD & Mean Difference \\
& 92 & 29.92 & 5.31 & 54.65 & 9.18 & 24.73 \\
Control Group & 88 & 29.95 & 5.13 & 42.94 & 11.23 & 12.99 \\
Total & 180 & 29.93 & 5.30 & 48.79 & 11.77 & 18.86 \\
\hline
\end{tabular}

Evidence from table 1 shows that participants exposed to training instructions had the highest mean difference of 24.73, whereas the control group had 12.99. To determine whether significance difference exists in Basic Science Achievement scores among participants, one-way ANCOVA was used and the results are presented in Table 2.

Table 2: ANCOVA Test of difference in post-test BS Achievement Test between Training and control group

\begin{tabular}{|c|c|c|c|c|c|c|c|}
\hline Source & & $\begin{array}{c}\text { Type Ill sum of } \\
\text { square }\end{array}$ & Df & $\begin{array}{c}\text { Means of } \\
\text { square }\end{array}$ & F & Sig. & $\begin{array}{c}\text { Partial Eta } \\
\text { squared }\end{array}$ \\
\hline \multirow{2}{*}{$\begin{array}{l}\text { corrected } \\
\text { covariates }\end{array}$} & model & 7504.363(a) & 2 & 3752.181 & 38.32 & .000 & .320 \\
\hline & & 1337.887 & 1 & 1337.887 & 13.66 & .000 & .072 \\
\hline $\begin{array}{l}\text { experimental } \\
\text { conditions }\end{array}$ & & 6183.048 & 1 & 6183.048 & 63.15 & .000 & .263 \\
\hline $\begin{array}{l}\text { Error } \\
\text { correction total }\end{array}$ & & $\begin{array}{l}17327.698 \\
24832.061\end{array}$ & $\begin{array}{l}177 \\
179\end{array}$ & 97.897 & & & \\
\hline
\end{tabular}

*significant at 0.05; $d f=1 \& 177, F$-cal $=63.15 ; F$-critical $=3.91$ 
The ANCOVA result presented in Table 2 shows that for the experimental condition, the F-value obtained was 63.15 as $\mathrm{P}$-value $<0.05$, given 1 and 177 degrees of freedom at the .05 level of significance. This therefore suggests that training on cooperative learning was effective in the Basic Science Achievement of the students. Therefore hypothesis 1 was rejected. This also showed that cooperative learning training had impact on the participants than their control Group counterparts.

Hypothesis Two: There is no significant difference in post-test Basic science Achievement Test Scores due to Gender and Experimental conditions.

Table 3: Descriptive Data on Pre and Post test scores of participants between Experimental conditions and Gender in Basic Science

\begin{tabular}{|c|c|c|c|c|c|c|c|}
\hline \multicolumn{2}{|l|}{ SOURCE } & \multicolumn{3}{|c|}{ Pre-test Scores } & \multicolumn{3}{|c|}{ Post-test Scores } \\
\hline Experimental & & & & Std. & & Std. & Mean \\
\hline Group & $\mathrm{N}$ & Gender & Mean & Deviation & Mean & Deviation & Difference \\
\hline \multirow[t]{3}{*}{ Training group } & 48 & Male & 30.5 & 5.79 & 56.35 & 10.35 & 25.76 \\
\hline & 44 & Female & 29.36 & 4.86 & 53.22 & 7.89 & 23.86 \\
\hline & 92 & Total & 29.92 & 5.31 & 54.65 & 9.18 & 24.73 . \\
\hline \multirow[t]{3}{*}{ Control group } & 47 & Male & 30.33 & 5.18 & 44.22 & 12.06 & 13.89 \\
\hline & 41 & Female & 29.17 & 5.63 & 40.34 & 8.97 & 11.17 \\
\hline & 88 & Total & 29.95 & 5.33 & 42.94 & 11.23 & 12.99 \\
\hline \multirow[t]{3}{*}{ Total } & 95 & Male & 30.44 & 5.42 & 49.26 & 12.82 & 18.82 \\
\hline & 85 & Female & 29.29 & 5.12 & 48.49 & 10.34 & 19.2 \\
\hline & 180 & Total & 29.93 & 5.30 & 48.92 & 11.77 & 18.99 \\
\hline
\end{tabular}

Evidence from tablen3, shows that the male and female participants exposed to training instruction on cooperative learning had a mean difference of (25.76 and 23.86), whereas, the control group had a mean difference of (13.89 and 11.17) for male and female participants respectively. This shows that male students did better than their female counterparts. To determine whether significant difference exist due to gender and experimental conditions, two-way ANCOVA was utilized and the results are presented in table 4.

Table 4: ANCOVA tests of the effects of Experiential Condition and Gender on Post-test Basic Science (BS) Achievement test of students

\begin{tabular}{|c|c|c|c|c|c|c|}
\hline Source & $\begin{array}{l}\text { Type Ill sum of } \\
\text { square }\end{array}$ & Df & $\begin{array}{l}\text { Mean } \\
\text { Square }\end{array}$ & $\mathbf{F}$ & Sig. & $\begin{array}{l}\text { Partial } \\
\text { Eta } \\
\text { square }\end{array}$ \\
\hline Corrected model & 7859.880(a) & 4 & 1964.970 & 20.261 & .000 & .317 \\
\hline Pre- BS & 1176.729 & & & & & \\
\hline Achievement & & 1 & 1176.729 & 12.133 & .001 & .065 \\
\hline Gender & 354.492 & & & & & \\
\hline Experimental & & 1 & 354.492 & 3.655 & .058 & .020 \\
\hline Conditions & 6453.107 & & & & & \\
\hline Experimental & & 1 & 6453.107 & 66.538 & .000 & .275 \\
\hline Condition*Gender & 6.253 & & & & & \\
\hline Error & 16972.181 & 1 & 6.253 & .064 & .800 & .000 \\
\hline Corrected total & 24832.061 & $\begin{array}{l}175 \\
179\end{array}$ & 96.984 & & & \\
\hline
\end{tabular}

*significant at $0.05 ; \mathrm{df}=1 \& 177, F$-cal $=66.53 ; \mathrm{F}$-critical $=3.91$

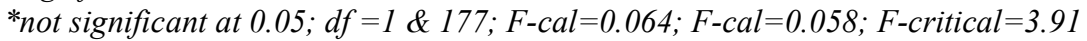

The ANCOVA results presented in table 4 shows that F-value obtained for gender was 3.655 as p-value. $>.05$, given 1 and175 degrees of freedom at the .05 level of significance. This shows that there is no significant gender difference between male and female students in BS. The F-value of experimental condition was 66.53 as P-value $<.05$, given 1 and 175 degrees of freedom at the .5 level of significance. This shows that there is significance gender difference between male and female students in Basic Science. For interaction between gender and experimental conditions, the F-value was .064 as P-value. >.05, given 1 and 175 degree of freedom at the .05 level of significance. The result therefore accepted the null hypothesis, therefore there is no significance interaction effect between gender and experimental conditions. 
Discussion of findings

The finding in hypothesis one shows that there is a significant difference in the post-test scores of Basic Science achievement among participants exposed to two experimental conditions. In support of this findings, Johnson and Johnson, (1987) and Yamarick, (2007) carried out a study to determine the influence of cooperative learning approach to students' performance. The study found that participants who were exposed to cooperative learning approach performed better than those who used conventional approach. The reason for the difference could be attributed to acquisition of training on cooperative learning which were infused in the teaching of Basic Science.

The findings in hypothesis two shows that there was no significant interaction effect between gender and experimental conditions in post-test Basic Science achievement test scores. In support of this findings, Kaur and Gill (2009) revealed that achievement in English language and total achievement was independent of Sex, but boys scored higher than girls in mathematics, BS and science. Sprigler and Alsup, (2003) carried out a study on gender achievement and found out that there was no gender difference on mathematical reasoning ability at elementary level. Moreover, Ding, Song and Richardson, (2007) were in support of that there was no significant difference between male and female students in mathematics. This can be attributed to the awareness of the importance of the subject by both Sexes in the society and that one hardly survives without it.

\section{Conclusion}

Based on the result obtained in the study, it is therefore concluded that cooperative learning and peer assessment enhances effective understanding and comprehension of Basic Science concept and skills acquisition, therefore it should be used in teaching secondary school students.

\section{Recommendations}

Based on the findings, the following are recommended.

1. The use of cooperative strategies should be given emphasis in the curriculum of teachers' education

2. Basic Science teachers should be trained and retrained in the use of cooperative learning in teaching and learning processes.

3. There should be proper provisions of facilities which are necessary for effective cooperative learning strategies.

4. The Ministry of education and Head of schools should ensure that teachers implement the use of cooperative learning to assess their students in schools because it involves team work which is linked to self-direction and boost confidence. Ultimately, teachers will teach the students how to develop selfdirecting learning which may enhance their academic performance in Basic Science. This will also help the students to communicate their Basic Science ideas in writing, symbolically, visually, use Basic Science vocabulary, notation, and structure to represent ideas, and describe their relationships.

\section{References}

Abu, R., \& Flowers, J. (2009). The effects of cooperative learning methods on achievement, Retention and attitudes of home economics students in North Carolina. Journal of Vocational and Technical Education, 13, (2), 230-234.

Becker, W. E., \& Watts, M. (2001). Teaching economics at the $21^{\text {st }}$ century: Still chalk and Talk. American Economic Review Paper and Proceedings, 91, (2), 440-445.

Benzing, C., \& Christ, P. (2007). A survey of teaching methods among economics faculty. Journal of Economic Educations. 28, 182-188.

Brooks, T. B., \& Khandler, A. W. (2002). A cooperative learning lab: Does the form matter? Contemporary Economic Policy, 20, (3), 330-338.

Ding, C. S., Song, K. \& Richardson, 1. 1. (2007). Do mathematical difference continue? Educational Study, 23, (45), $279-295$.

Felder, R. M., Felder, G. N. \& Dietz, E. J. (1998). A longitudinal study of engineering performance and retention. V. Comparison with traditionally taught students. Journal of Engineering Education, 20, (1), 6-10.

Goor, M. B., \& Schwenn, J. O. (2013). Accommodating diversity and disability with Cooperative learning. Intervention in School and Clinic, 29, (1), 6-16.

Holtfreter, R. E., \& Holtftreter, K. E. (2000). A comparison of students' attitudes and beliefs of lecturer/discussion and cooperative approaches to learning in an accounting classroom. http://www.cwu.edu/-holtfret/Articles?Comparison.html 
Jensen, E. J., \& Owen, A. L. (2001). Pedagogy, gender and interests in economics. Journal of Economic Education, 34, (2), 323-343

Johnson, D.W \& Johnson, R. T. (1987). Learning together and alone. Englewood Practice Hall.

Johnson, D. W., Johnson, R. T., \& Holubec, E. J. (1986). Circle of Learning: Cooperation in the Classroom. Edina MN: Interaction Book Company.

Johnson, D. W., Johnson, R. T., \& Stanne, M. B. (2000). Cooperative learning methods: A Meta Analysis. www.cooperation.org/pages/cl-methods.html . Retrieved: 6 May 2013

Johnson, D. W., Johnson, R. T., \& Smith, K. A. (1998). Cooperative learning methods: A meta-analysis www.cooperation.org/pages/cl-methods.html. Retrieved: 6 may 2013.

Johnson, D. W., Johnson, R. T., \& smith, K. A. (1998). Cooperative learning returns to college: What evidence is there that it works? Change, 30 (4), 20-35

Kaur, R., \& Gil, T. K. (2009). Sex differences in academic achievement in different subjects of rural urban students. Indian Psychological Review, 40, (12), 20-24.

Moore, R. L. (1998). Teaching introductory economics with a cooperative learning lab. Journal of Economic Education, 29, 321-329.

Odili, S. F. (2009). Teaching Mathematics in the Secondary School. Port-Harcourt: Amaduna Educational books.

Ronsini, B. A. (2010). The effect of cooperative learning of methods on achievement, Retention attitude of home economics students in northern Carolina. Education Research, 2, 20-25

Samuelson, P. A., \& Nordhaus, W. D. (2000). Nature and Scope of Economics, $16^{\text {th }}$ Lriwin/McGraw-Hill

Sapon-Shevin, M., \& Schniedewind, N. (2009). If cooperative learning's the answer, what are the Questions? Journal of Education, 174, (2), 11-37.

Slavin, R. E. (2011). Student team learning in mathematics. In N Davidson (Ed). Cooperative Learning in mathematics: A Handbook for Teachers. Menlo Park CA: Addison-Westley.

Springler, D. M. \& Alsup, J. K. (2003). An analysis of gender and the mathematical reasoning Ability subskill of analysissynthesis. Education, 4, (123), 27-38.

Vijayalaxmi, N. \& Natesan, H. (2012). Factors influencing academic achievement. Research Highlight, 2, (5) 62-84.

Voigt, P. H., \& stander, H. (1991). Vakdidaktiek: Rekeningkunde Vir die sekondere skool. Pretoria: De Jager-HANUM utigewers

Whicker, K. M., Bol, L., \& Nunnery, J. A. (1997). Cooperative learning in the secondary Mathematics classroom. Journal of Educational Research, 91, (1), 42-48.

Wittrock, M. C. (2008). The cognitive movement in instruction. Educational Psychologist, 13, (2) 15-29.

Yamarick, S., (2007). Does cooperative learning improve student learning outcomes? Journal of Economics Education Summer, 6, 259-277.

Zahariah, M. Z., Geetha, S., Arlinah, R., \& Erlane, K. G. (2009). Teaching economics using cooperative learning approach: Accounting students' performance and Attitude. Canadian Social Science, 5, (6), 92-102. 